\title{
HUBUNGAN ANTARA MINAT BACA DENGAN PRESTASI BELAJAR MURID KELAS V SD
}

\author{
Nurfadilla, Rosleny \\ Pendidikan Guru Sekolah Dasar, Fakultas Keguruan dan Ilmu Pendidikan \\ Universitas Muhammadiyah Makassar \\ Maulidhaluph@yahoo.co.id
}

\begin{abstract}
ABSTRAK
Jenis penelitian ini korelasional, pada penelitian ini untuk mengetahui tingkat hubungan antara dua variabel yaitu satu variabel bebas (independent) dan satu variable terikat (dependent). Populasi dalam penelitian ini adalah murid Kelas Va SDN Minasa Upa Kecamatan Rappocini Kota Makassar tahun pelajaran 2017/2018 dengan jumlah 28 orang murid dan sampelnya adalah murid kelas Va dengan jumlah 28 orang murid. teknik pengambilan sampel menggunakan purposive sampling. Teknik pengumpulan data dilakukan dengan menggunakan angket, dan prestasi belajar. Data dianalisis dengan menggunakan tekhik kuantitatif. Hipotesis Ha: Terdapat hubungan yang signifikan antara anatara minat baca dengan prestasi belajar murid. Ho: Tidak terdapat hubungan yang signifikan antara minat baca dengan prestasi belajar murid. Hasil penelitian memberikan gambaran bahwa: Hasil analisis yang diperoleh secara perhitungan menggunakan persamaan koefisien korelasi produk moment yaitu sebesar 0,465 lebih besar dari nilai koefisien korelasi produk moment pada tabel 0,537 pada taraf signifikan 1\%dan 0,381 pada taraf signifikan 5\% dengan derajat kebebasan 23-1 = 28 atau $r_{\text {hitung }}>r_{\text {tabel }}$ dapat disimpulkan bahwa "Ada hubungan yang positif dan signifikan antara minat baca dengan presstasi belajar murid kelas V SDN Minasa Upa Kecamatan Rappocini Kota Makssar", dengan kategori cukup kuat terhadap hasil belajar murid.
\end{abstract}

Kata Kunci: Minat Baca Dengan Prestasi Belajar Murid

\begin{abstract}
ABSTRAK
This type of research is correlational, in this study to determine the level of relationship between two variables ie one independent variable (independent) and one dependent variable (dependent). The population in this study were students of Class Va SDN Minasa Upa Kecamatan Rappocini Kota Makassar 2017/2018 academic year with the number of 28 students and the sample is a class student of Va with the number of 28 students. sampling technique using purposive sampling. Data collection techniques were conducted using questionnaires, and learning achievement. Data were analyzed using quantitative technique. Hypothesis Ha: There is a significant relationship between reading interest with student achievement. Ho: There is no significant relationship between reading interest and student achievement. The results of the study provide a description that: The results obtained by calculation analysis using the equation product moment coefficient coefficient of 0.465 is greater than the value of product moment correlation coefficient on the table 0,537 at a significant level of $1 \%$ and 0.381 at $5 \%$ significant level with degrees of freedom $23-1=28$ or rhitung $\neg>$ rtabel it can be concluded that "There is a positive and significant correlation between reading interest with presstasi learn class V SDN Minasa Upa Kecamatan Rappocini Kota Makssar", with strong enough category to student learning result.
\end{abstract}




\section{PENDAHULUAN}

Berbicara tentang kualitas pendidikan, rasanya tidak dapat kita pisahkan dari hasil belajar ataupun juga prestasi murid. Kondisi murid yang berbeda kemampuannya antara individu satu dengan individu lainnya turut mempengaruhi pula pada hasil belajar dan prestasi yang mereka raih di sekolah. Kemampuan disini dapat diartikan sebagai kemampuan untuk berkomunikasi, bersosialisasi, ataupun juga kemampuan kognitif.

Kemampuan berkomunikasi
adalah kemampuan anak untuk
menyatakan buah pikirannya dalam
bentuk ungkapan kalimat yang bermakna, logis dan sistematis. Kemampuan bersosialisasi pada murid pun berbeda antara individu yang satu dengan individu lainnya. Kemampuan kognitif berkaitan dengan kemampuan murid menguasai suatu ilmu pengetahuan dan teknologi. Pada dasarnya kemampuan kognitif diperoleh karena adanya proses belajar. Tingkat kemampuan kognitif masingmasing murid akan tergambar dari hasil belajar yang diukur melalui tes hasil belajar. Tes hasil belajar dapat menghasilkan nilai kemampuan kognitif yang bervariasi. Faktor intelektualitas atau kecerdasan mempunyai pengaruh yang besar terhadap perkembangan kognitif anak. Jadi dapat pula dikatakan bahwa semakin tinggi nilai kecerdasan anak, maka semakin tinggi pula kemampuan kognitifnya.

Mengacu pada hal-hal yang telah dikemukakan tersebut, penulis merasa ada suatu ketidaksesuaian antara teori dengan kenyataan yang terjadi di SD Negeri Minasa upa kacamatan rappocini kota Makassar. Prestasi yang diraih SD Negeri Minasa upa kacamatan rappocini kota Makassar bisa dikatakan bagus, namun dengan melihat perpustakaan sekolah yang sepi pengunjung menimbulkan pertanyaan apakah murid SD Negeri Minasa upa kacamatan rappocini kota Makassar. Memiliki minat untuk membaca? Apakah dalam kesehariannya di rumah, murid memiliki minat untuk membaca? Berkaitan dengan hal tersebut, penulis juga ingin mengetahui bagaimana aktifitas belajar murid di rumah yang berkaitan dengan kontinuitas belajarnya.

Dampak dari kurangnya minat membaca murid juga diikuti oleh kurangnya kontinuitas belajar murid. Hal 
ini bisa dipahami karena sebagian besar aktifitas belajar murid adalah melalui membaca. Faktor dukungan dari keluarga, baik dukungan secara psikologis maupun kelengkapan belajar, sering menjadi alasan bagi murid tidak merasa nyaman dalam melakukan kegiatan belajar di rumah. Akibat dari tidak adanya kontinuitas murid dalam belajar menyebabkan aktifitas belajar yang dilakukan murid menjadi tidak teratur. Tidak teraturnya aktifitas belajar menyebabkan tidak optimalnya penguasaan materi yang dikuasai murid. Akibat dari hal-hal tersebut, prestasi hasil belajar yang diperoleh murid juga kurang maksimal.

Berdasarkan identifikasi masalah yang telah dikemukakan sebelumnya, penulis merumuskan masalah yang akan diteliti adalah "Apakah ada hubungan antara minat baca dengan prestasi belajar murid kelas V Sekolah SD Negeri Minasaupa Kecamatan Rappocini Kota Makassar?. Tujuan penelitian ini adalah untuk mengetahui hubungan antara minat baca dengan prestasi belajar murid kelas V SD Negeri Minasa upa Kecamatan Rappocini Kota Makassar.

\section{Minat Baca}

Minat merupakan dorongan dari dalam diri seseorang atau faktor yang menimbulkan ketertarikan atau perhatian secara selektif, menyebabkan pilihannya suatu obejek atau kegiatan menguntungkan, menyenangkan dan lama kelamaan akan mendatangkan kepuasan dalam dirinya (Mikarsa 2010: 3.5), Minat adalah kecenderungan dalam diri individu untuk tertatik pada sesuatu objek atau menyenangi sesuatu objek ( Sumadi Suryabrata, 1988 : 109 ). Menurut Crow and Crow minat adalah pendorong yang menyebabkan seseorang memberi perhatian terhadap orang, sesuatu, aktivitas-aktivitas tertentu. ( Johny Killis, $1988: 26$ ).

Jika merujuk pada definisi-definisi dari para ahli tersebut, dapat disimpulkan bahwa minat berarti kecenderungan hati yang tinggi terhadap sesuatu .minat merupakan sifat yang relatif menetap pada diri seseorang. Dengan minat, seseoang akan melalukan sesuatu yang diminatinya tersebut. Sebaiknya, tanpa adanya minat, seseorang tidak akan melakukan sesuatu yang tidak diminatinya tersebut. 
Membaca merupakan proses memperoleh mkna dari benda cetak. Diperoleh secara langsung ataupun juga tidak langsung. Pengajaran membaca sangat tepat diguanakan sebagai sarana untuk mengarahkan murid menjadi pembaca yang mandiri dan juga dapat digunakan sebagai upaya menumbuhkan minat membacapada murid (Rofi'uddin 2002: 31).

\section{Pembelajaran}

membaca diselenggarakan untuk bisa mengembangkan kemampuan membaca yang dimiliki murid untuk mengembangkan dirinya. Dengan membaca, murid diharapkan memiliki kemampuan untuk menyerap berbagai pengetahuan yang sebagian besar disampaikan melalui tulisan. Selain itu, membaca juga merupakan keahlian yang mutlak dimiliki murid sebagai indikator belajar berkaitan dengan aktifitas menulis dan berbicara.

Dari pendapat-pendapat yang dikemukakan para ahli tersebut, dapat Ditarik kesimpulan bahwa pada umumnya membaca adalah aktifitas melihat tulisan (dengan dilisankan ataupun tidak dilisankan) dan bertujuan untuk mengetahui isi dari tulisan tersebut. Tujuan membaca sendiri adalah untuk memperoleh pesan/informasi yang ingin disampaikan penulis kepada pembaca. Membaca merupakan proses komunikasi karena pembaca akan menangkap, memahami ide ataupun juga pesan penulis yang dituangkan dalam bentuk tulisan.

Dari berbagai pendapat tersebut dapat disimpulkan bahwa minat membaca adalah motivasi dan keinginan yang kuat bagi seseorang untuk membaca. Keinginan membaca yang tinggi dalam diri seseorang tersebut dapat menimbulkan gairah untuk membaca sehingga seseorang akan selalu berusaha mendapatkan bahan bacaan untuk memenuhi kebutuhannya. Seseorang yang memiliki minat baca yang tinggi akan menjadikan aktifitas membaca sebagai suatu kebutuhan dan kebiasaan. Sebagai tindak lanjut dari keinginan membaca yang kuat, maka akan timbul kegemaran membaca.

\section{Prestasi Belajar}

Prestasi adalah suatu kegiatan yang telah dikerjakan, diciptakan baik secara individual atau kelompok. Dalam Kamus Besar Bahasa Indonesia, yang dimaksud dengan prestasi adalah hasil 
yang telah dicapai (dilakukan, dikerjakan dan sebagainya. Prestasi adalah apa yang telah dapat diciptakan, hasil pekerjaan, hasil menyenangkan hati, diperoleh dengan jalan keuletan kerja. Dapat dikatakan pula bahwa prestasi adalah penilaian pendidikan tentang perkembangan dan kemajuan murid berkenaan dengan penguasaan bahan pelajaran yang disajikan kepada murid.

Prestasi belajar adalah kesankesan yang mengakibatkan perubahan dalam diri individu sebagai hasil dari aktifitas dalam belajar (Djamarah 1994: 23 .Prestasi hasil belajar merupakan suatu perubahan yang dicapai seseorang setelah mengikuti proses belajar. Perubahan ini meliputi perubahan tingkah laku secara menyeluruh dalam sikap, keterampilan dan pengetahuan".

Menurut Tu'u (Mulyani 2006: 29), prestasi hasil belajar adalah "penguasaan pengetahuan atau keterampilan yang dikembangkan oleh mata pelajaran, lazimnya ditunjukkan oleh nilai tes atau nilai dari guru". Sedangkan menurut W.S. Winkel (Mulyani 2006: 29), prestasi hasil belajar adalah "keberhasilan usaha yang dicapai seseorang setelah memperoleh pengalaman belajar atau mempelajari sesuatu". Prestasi hasil belajar yang diperoleh dapat mewujudkan kualitas belajar tinggi atau sebaliknya. Hal ini tergantung dari usaha dan kemampuan masing-masing individu di samping adanya faktor-faktor yang mempengaruhi hasil tersebut.

\section{METODE PENELITIAN}

Penelitian ini merupakan penelitian korelasional, dimana pada penelitian ini untuk mengetahui tingkat hubungan antara dua variabel yaitu satu variabel bebas (independent) dan satu variable terikat (dependent). Desain penelitian ini berjenis penelitian ex post facto. Pemilihan metode tersebut dengan pertimbangan bahwa penelitian ini merupakan penelitian kuantitatif non eksperimental dengan model penelitian deskriptif korelasional. Penelitian korelasional merupakan penelitian yang dimaksudkan untuk mengetahui ada atau tidaknya hubungan antara dua variabel atau lebih.

Populasi dalam penelitian ini adalah seluruh murid SD Negeri Minasaupa Kecematan Rappocini Kota Makassar, mulai dari kelas 1 sampai kelas $\mathrm{V}$ Berdasarkan data yang diperoleh 
jumlah keseluruhan murid adalah 224 murid. Teknik pengambilan sampel yaitu mengunakan sampling jenuh, sampling jenuh adalah sampel yang mewakili jumlah populasi. Biasanya dilakukan jika populasi dianggap kecil atau kurang dari 100. Jadi sampel dari penelitian ini adalah keseluruhan murid adalah 28 murid. Analisis data adalah suatu kegiatan setelah data dari seluruh sumber data yang terkumpul. Analisis data yang digunakan dalam penelitian ini adalah Uji Validitas

\section{HASIL PENELITIAN DAN PEMBAHASAN}

Pada bagian ini akan diuraikan hasil yang ditemukan dalam penelitian dalam penelitian . hasil yang dimaksudkan yaitu kesimpulan yang diambil berdasarkan data yang terkumpul dan analisis data yang telah dilakukan.

Hasil analisis data memperlihatkan bahwa dari 22 jumlah murid yang menjadi sampel penelitian, maka diperoleh nilai hitung $\mathrm{r}_{\text {hitung }}$ sebesar 0,465 .

Untuk mengetahui nilai pengujian hipoteis penelitian maka nilai $\mathrm{r}_{\text {hitung }}$ dihubungkan dengan $r_{\text {tabel }}$ pada taraf signifikan 5\% kriteria pengujian hipotesis adalah sebagai berikut:

1. Jika nilai $\mathrm{r}_{\text {hitung }}$ lebih besar dari pada $\mathrm{r}_{\text {tabel }}$ maka hipotesis diterima.

2. Jika nilai $r_{\text {hitung }}$ lebih kecil dari pada nilai $r_{\text {tabel }}$ maka hipotesis ditolak.

3. Nilai $r_{\text {tabel }}$ yang digunakan sebagai pembanding yaitu diketahui dengan cara mencari nilai yang berada pada taraf signifikan $5 \%$ dan $\mathrm{N}=22$

Pengujian analisis data menunjukkan nilai $\mathrm{r}_{\text {hitung }}$ sebesar 0,465 jumlah korelasi merupakan hasil dari analissis product moment yang diambil dari hasil tes melalui pengajaran mengunakan minat baca dan prestasi belajarsedangkan nilai $r_{\text {tabel }}$ sebesar 0,381 hal ini dapat diperoleh dapat taraf signifikan 5\% dengan $\mathrm{N}=22$ Hasil olahan data dari nilai penerapan minat baca dengan prestasi belajar murid, membuktiakan bahwa nilai analisis $\mathrm{r}_{\text {hitung }}$ lebih besar dari pada nilai $r_{\text {tabel }}$ maka hipotesis yang diajukan dalam penelitian ini diterima dan terdapat hubungan yang signifikan anatara penerapan minat baca dan prestasi belajar murid SDN Minasa Upa Kecamatan Rappocini Kota Makassar. 


\section{KESIMPULAN DAN SARAN}

Berdasarkan hasil analisis yang ditunjukkan pada pembahasan sebelumnya, hasil pengujian secara parsial menunjukkan, variabel minat baca dengan prestasi belajar murid SDN Minasa Upa Kecamatan Rappocini Kota Makassa. Hasil analisis yang diperoleh secara perhitungan menggunakan persamaan koefisien korelasi produk moment yaitu sebesar 0,465 lebih besar dari nilai koefisien korelasi produk moment pada tabel 0,381 pada taraf signifikan $1 \%$ dan 0,432 pada taraf signifikan 5\% dengan derajat kebebasan 23-1 = 22 atau $r_{\text {hitung }}>r_{\text {tabel }}$ dapat disimpulkan bahwa "Ada hubungan yang positif dan signifikan antara minat baca dan prestasi belajarmurid SDN Minasa Upa Kecamatan Rappocini Kota Makassar".

Berdasarkan kesimpulan di atas, maka penulis memberikan beberapa saran sebagai berikut (1) Kepala sekolah hendaknya lebih meninggkatkan pembinaan dan wawasan kepada guru agar tepat konsisten membimbing siswa dalam menumbuhkan prestasi belajar murid dalam proses pembelajaran. (2) Bagi guru, SDN Minasa Upa Kecamatan
Rappocini Kota Makassar diharapkan agar meninggakatkan kreativitasnya dalam mengajar supaya prestasi muridmurid lebih meninggakat. (3) Bagi murid, agar lebih membiasakan diri menjadi lebih aktif, objektif dan lebih serius mengerjakan tugas baik tugas di rumah ataupun di sekolah yang diberikan oleh guru. (4) Kepada peneliti lain agar penelitian ini bisa menjadi rujukan ilmu untuk perkembangan penelitian selanjutnya.

\section{DAFTAR PUSTAKA}

Anni, Catharina, Tri, dkk. 2007. Psikologi Belajar. Semarang: UNNES press.

Arikunto, Suharsimi. 2006. Prosedur Penelitian Suatu Pendekatan Praktik (cetakan ke XIII). Jakarta: Rineka Cipta.

Kusuma, R .2011. UJi Asumsi Klasik. (Online) dari (http:// www.hamzaaak.co.cc/2011/06/ uji-asumsiklasik.html), (18/06/2017).

Mikarsa, 2009. Pendidikan Anak di SD (cetakan ke XIII). Jakarta: Universitas Terbuka.

Mulyani, Nanik. 2006. Pengaruh Motivasi Berprestasi, Kontinuitas Belajar dan Fasilitas Belajar Terhadap Prestasi Belajar Murid Kelas XI MA Banat NU Kudus. Skripsi Universitas Negeri Semarang. 
Munib, Achmad, dkk. 2007. Pengantar Ilmu Pendidikan. Semarang: UNNES press.

Musfiroh, Takdiroatun. 2009. Menumbuhkembangkan Baca-Tulis Anak. Jakarta:Grasindo.

Priyatno, Duwi. 2010. Paham Analisa Statistik Data dengan SPSS. Yogyakarta:Mediakom.

-. 2010. Teknik Mudah dan Cepat Melakukan Analisis Data Penelitian dengan SPSS. Yogyakarta: Gava Media.

Rofi'uddin, Ahmad, dkk. 2002. Pendidikan Bahasa dan Sastra Indonesia di Kelas Tinggi (cetakan ke II). Malang: Universitas Negeri Malang.

Sanjaya, Ade. 2011. Pengertian, Definisi Hasil Belajar Murid. (online). http://aadesanjaya.blogspot.com/2 011/03/pengertian-definisi-hasilbelajar.html,diakses (15/09/2017).

Sanjaya, Ade. 2011. Pengertian Prestasi Belajar. (Diakses) (http://www. Pengertian prestasi belajar) Diakses (15/09/2017)

Santosa, Puji, dkk. 2009. Materi dan Pembelajaran Bahasa Indonesia SD (cetakan ke XIII). Jakarta: Universitas Terbuka. 